\title{
Sciendo
}

Administration, vol. 70, no. 1 (2022), pp. 31-47

doi: 10.2478/admin-2022-0003

\section{Local government, 2021}

\author{
Fergal O'Leary \\ Institute of Public Administration, Ireland
}

The second year of the pandemic saw local government continue its determined response to address the crisis: supporting communities and businesses, communicating with the public and assisting in the vaccination programme. Covid-era work practices remained in place for staff and councillors, as did changes in the model of service delivery for the public. Hopes for a return to more normal times after a successful vaccination roll-out were dashed by the Omicron wave of infections in late 2021. As the pandemic progressed, with everyday life disrupted by varying levels of restrictions, mental health and economic security became bigger societal concerns, and remain so today. In this context, well-being initiatives and business supports at local level were particularly urgent.

Of course, other policy issues have not gone away and local authorities remain at the forefront of efforts to grapple with housing shortages and climate change. The first full year of the Fianna Fáil/Fine Gael/Green Party government witnessed the publication of numerous policies and plans - in line with commitments in the programme for government - many of which place local authorities at the centre of implementation. With continued growth in the Irish economy, more resources were made available to the sector to carry out its broad work programme. Indeed, 2021 saw the number of staff employed in local authorities exceed 30,000 for the first time in ten years. 


\section{Community development}

In February, against the backdrop of Level-5 restrictions and a vaccination programme in its early stages, the government published COVID-19 Resilience and Recovery 2021 - The Path Ahead (Department of the Taoiseach, 2021). The role of local authorities was clearly outlined in the area of well-being and mental health. In 2021 they were heavily involved in the organisation of initiatives linked to the 'Keep Well' outreach campaign. For example, as part of the Resilience and Recovery plan, all councils were behind a programme of creative activities aimed at encouraging people to switch off and get in touch with their creative side (Dáil Éireann, 2021).

March saw the publication of Our Rural Future: Rural Development Policy 2021-2025 (Department of Rural and Community Development, 2021), intended as a blueprint for a post-pandemic recovery and for the development of rural Ireland over the next five years. To help realise its vision of a 'thriving rural Ireland', the strategy links several policy priorities such as digital connectivity, supporting employment in rural areas, revitalising towns and villages, enhancing local participation and leadership, improving public services and the transition to a carbon neutral society. Whilst a strategic and holistic effort is necessary, Our Rural Future recognises that a one-size-fits-all policy cannot effectively meet the different needs of rural Ireland and so advocates a place-based approach. Therefore, the plans of local authorities (development plans, area plans, climate plans, etc.), fully aligned with national policies and strategies, will be pivotal. The policy's commitments include:

- developing and implementing culture and creative strategies and local digital strategies in each local authority area;

- providing dedicated local authority staff to support town centre renewal;

- enhancing the powers of local authorities to offer commercial ratesbased incentives for businesses, targeting the re-use of vacant commercial units.

Considerable physical development work has been undertaken by local authorities in recent years around Ireland, with numerous projects completed and many more planned. Continued funding from the Rural Regeneration and Development Fund and the Town and Village Renewal Scheme will be crucial to build on the momentum in 
respect of revitalising towns and villages and advancing regional development.

The preparation process for the next iteration of the six-year local economic and community plans (LECPs) began in late 2021. A policy innovation introduced back in 2015, the LECP adopted by each council outlines goals and actions to foster economic and community development. New guidelines for the next round of LECPs were published jointly in November by the Department of Rural and Community Development and the Department of Housing, Local Government and Heritage (DHLGH). The consultation process undertaken for the preparation of the latest guidelines identified valuable lessons from the current LECP cycle to inform the next.

The LECP process needs to be more flexible in terms of being able to incorporate emerging needs over the course of the plan. Furthermore, the new LECPs ought to take greater account of the resources available locally to better prioritise actions for delivery. The guidelines repeatedly stress the point that the high-level actions in the new LECPs need to be realistic, achievable and practical (Department of Rural and Community Development and the Department of Housing, Local Government and Heritage, 2021). The pandemic has highlighted the importance of flexibility within the statutory planning process so that it can factor in unexpected events and their impacts on priorities and resources.

A number of key policy initiatives - linked to Sláintecare - were launched in 2021 which highlight the integration of health and wellbeing responsibilities into the community development work of local authorities. July saw the unveiling of the National Healthy Age Friendly Homes Programme to improve housing options for older citizens. The programme currently operates in nine local authorities (Healthy Age Friendly Homes Programme, 2021). The Sláintecare Healthy Communities Programme was launched in October and is a collaboration between statutory and non-statutory bodies. A group of local authorities will be central to an enhanced health and well-being service in nineteen disadvantaged communities around Ireland (Health Service Executive, 2021).

\section{Economic development and enterprise support}

Given their economic development and enterprise role, local authorities need to be well placed in the coming years to help businesses capitalise on opportunities arising from Ireland's transition 
to a low-carbon economy. In this context, 2021 saw the publication of the Climate Action Economic Opportunities: Local Authorities Supporting Enterprise Policy Analysis Report. This examined a raft of European, national and local policies and strategies to identify the likely economic opportunities of climate action, and the funding options that are available. The local-level opportunities include:

- development of green innovations and technologies;

- constructing, surveying, renovating and retrofitting of localauthority-owned buildings and infrastructure;

- conducting surveying projects for local authorities on their assets and infrastructures;

- maintaining and repairing local authority assets;

- landscaping contracts with local authorities;

- installation and maintenance of photovoltaic solar panels;

- replacement of gas boilers with heat pumps;

- development and management of remote and co-working hubs/facilities, broadband community points.

By highlighting such opportunities, and by helping to direct investment accordingly, local authorities can help businesses to benefit from climate action (County and City Management Association and Local Government Management Agency, 2021).

\section{Culture, heritage and tourism}

Given the toll of Covid-19 restrictions and lockdowns on society, local government's promotion of culture has perhaps never been more urgent. The positive influence of culture on people's mental health is well known. From Culture Night to local festivals and events, and initiatives for all age groups, councils continued to support, as much as possible, the cultural life of communities in 2021.

In February the Department of Tourism, Culture, Arts, Gaeltacht, Sport and Media opened the Outdoor Public Space Scheme 2021 in an effort to 'reimagine' our civic spaces in this Covid era. Local authorities were invited to apply for funding to provide outdoor spaces for year-round use that are future-proofed from a public health perspective (Department of Tourism, Culture, Arts, Gaeltacht, Sport and Media, 2021). For example, Wexford County Council successfully applied for funding to construct a new outdoor performance pavilion 
on the Wexford Quays (Wexford County Council, 2021). As councils endeavor to promote public well-being and recovery in the arts sector, they seek to provide safe public spaces to stage cultural activities.

Work to develop tourist attractions and recreational facilities continues apace. From new greenways to walking and bike trails, and the renovation of historic sites, the authorities are involved in a wide range of projects across the country. For example, in 2021, details on the development of visitor attractions - funded by Fáilte Ireland's Destination Town scheme - in Clare and Wicklow were announced (Clare County Council, 2021; Wicklow County Council, 2021); while in Waterford, work commenced on a major redevelopment - under the Rural Regeneration and Development Fund - of Mount Congreve House and Gardens (Lonergan, 2021). Despite reduced visitor numbers owing to the pandemic, the tourist role of local authorities in terms of developing, marketing and operating attractions still grows each year in line with their economic development remit.

The heritage work of local authorities received a financial boost in November when additional funding was announced by the Minister of State for Heritage and Electoral Reform, Malcolm Noonan, TD. The total funding allocated for the Built Heritage Investment Scheme and the Historic Structures Fund increased to $€ 8$ million for 2022 (an increase of $€ 2$ million on 2021). These schemes are administered by council staff and over 550 projects received funding in 2021 (Department of Housing, Local Government and Heritage, 2021j).

Near the end of the year, the DHLGH published $A$ Living Tradition: A Strategy to Enhance the Understanding, Minding and Handing on of Our Built Vernacular Heritage. This document notes that the conservation of Ireland's built vernacular heritage is becoming a bigger priority in local government as more vernacular buildings architecture associated with a specific place or era - are included on records of protected structures. However, it is noted that many councils do not have the resources to employ an architectural conservation officer. According to the department, it is important to 'understand and tackle the obstacles and disincentives that exist to the continued use or reuse of our vernacular' (Department of Housing, Local Government and Heritage, 2021a). In the policy drive to live sustainably, promote tourism and address a housing shortage, a stronger focus on protecting, renovating and reusing our built heritage makes eminent sense, but greater public appreciation of this heritage and financial incentives will be essential. 
Councils continued to play a leading part in the final phase of the Decade of Centenaries (2012-23). Local museums sought to respectfully mark the momentous and traumatic events leading up to Irish independence. For 2021 curators and staff worked with communities to develop exhibitions and events to engage and challenge the public. For example, Cavan County Museum held a major exhibition on the War of Independence, entitled 'United Under the Flag', that was the culmination of more than a year's research (Bradley, 2021).

\section{Housing issues}

The government's Housing for All - A New Housing Plan for Ireland was launched in September. The core policy objective is similar to earlier plans: 'everybody should have access to sustainable, good quality housing to purchase or rent at an affordable price, built to a high standard, and located close to essential services' (Department of Housing, Local Government and Heritage, 2021f). The reference to housing near essential services speaks to the need for sustainable living and good planning in modern Ireland. Housing for All, as the name suggests, will strive to meet the housing needs for all groups: first-time buyers, renters, low-income households, the homeless, those seeking to trade up and rightsize, and those living in urban and rural communities.

Local government's role in the delivery of new houses is clearly outlined. A new housing delivery action plan prepared by each council will provide a roadmap for local delivery. The plan commits to provide over 300,000 new homes by 2030 - including 90,000 social homes, 36,000 affordable houses and 18,000 cost-rental units.

Unlike its predecessor, Rebuilding Ireland, the Housing for All plan will reform aspects of social housing. For example, it promises a revised tenant purchase scheme and the reintroduction of a national differential rental scheme (the last one was abolished back in 1986), and a new Commission for Housing will look at the possibility of independent regulation for social housing.

With over 200 actions, Housing for All has a wide scope. It also sets out initiatives to tackle dereliction and vacant properties, rejuvenate towns and cities, and better utilise and protect our built heritage. Such ambitions, however, raise a question about the capacity of local government to deliver. Whilst staff levels and financial resources for the sector are increasing, along with the demands from other public 
bodies, local authorities still have 5,000 fewer staff than they had back in 2008.

In 2021 the local authorities spent the full budget ( $€ 15.5$ million in capital and $€ 5.8$ million in current spending) in relation to Travellerspecific accommodation. This was the second consecutive year that the full allocated budget was used. After some criticisms in recent years for underspending on Traveller accommodation, a change to the DHLGH's funding allocation process has been credited to this improved spending performance (Department of Housing, Local Government and Heritage, 2021i).

The government's $€ 2.2$ billion Defective Concrete Blocks Grant Scheme was launched in late November. Currently, the redress scheme only applies to affected dwellings in Donegal and Mayo, though it might subsequently be extended to other counties. Applications for a grant are made to the relevant local authority who will administer the scheme; however, given the scale of the task, the Housing Agency will provide support. There are an estimated 7,500 affected homes in Donegal and Mayo, of which a significant portion is social housing. In announcing the scheme, the Minister for Housing, Local Government and Heritage, Darragh O'Brien, TD, also outlined new measures to help prevent a recurrence (Department of Housing, Local Government and Heritage, 2021k). Given the policy commitments in relation to housebuilding, the retrofitting of homes and the remedial works associated with the mica crisis, pressures in Ireland's construction sector are likely to worsen in the coming years.

\section{Environment}

The evolution of Ireland's climate change policy marked key milestones in 2021. The County and City Management Association unveiled a strategy - Delivering Effective Climate Action 2030 - to support local government's ambition to lead on local climate action (County and City Management Association, 2021).

In July the Climate Action and Low Carbon Development (Amendment) Bill was signed into law. This new Act legally commits Ireland to the objectives of climate neutrality by 2050 and a 51 per cent reduction in greenhouse gas emissions by 2030. The Climate Act 2021 makes it clear that the state will 'pursue and achieve, by no later than the end of the year 2050, the transition to a climate resilient, biodiversity rich, environmentally sustainable and climate neutral economy' (Department of the Environment, Climate and Communications, 2021b). 
As recognised leaders in helping Ireland meet its climate objectives, the local authorities are allocated clear statutory responsibilities under the amending Act. They will each prepare a five-yearly climate action plan with mitigation and adaptation measures. The Act stipulates that, in making the plan, each authority shall consult and cooperate with adjoining local authorities and, where appropriate, coordinate with them in relation to climate action. Consultation with the public participation networks will also be necessary. Furthermore, when preparing their statutory development plans, each local authority needs to take account of its own climate action plan (Climate Action and Low Carbon Development (Amendment) Act, 2021).

The government's new Climate Action Plan 2021 was unveiled in November. It replaces the Climate Action Plan 2019 and the 2017 National Mitigation Plan. The latter was quashed by the Supreme Court in 2020 because it was not specific enough to comply with the 2015 Climate Act. Under this new national plan, local authorities are expected to develop a rigorous response to climate action locally. They are described as having 'a pivotal decarbonisation role' through spatial planning, the provision of public housing and transport infrastructure, and the maintenance of biodiversity. Some of the specific measures relating to local government include:

- each local authority will develop a decarbonisation zone within its administrative area that will be a focus for mitigation, adaptation and biodiversity measures;

- the local authorities will play a key role in developing partnerships with local communities and community development organisations to progress community activation and climate action;

- the local authority retrofit programme will be expanded (Department of the Environment, Climate and Communications, 2021a).

Turning to local government and its water-quality role, the secondcycle River Basin Management Plan (RBMP) ended in 2021, so September saw the opening of public consultation on the draft management plan for 2022-7. This draft plan strives for a new level of ambition and outlines over 100 measures to address impacts on water quality. Among its core objectives, the draft RBMP seeks to tackle nutrient pollution from agricultural land, improve wastewater infrastructure and restore free-flowing waters. 
Local authorities have responsibilities in the governance of the RBMP, particularly with respect to the implementation and monitoring of measures on the ground. In this context, the draft RBMP commits to providing the necessary resources to better support local authorities in their role (Department of Housing, Local Government and Heritage, 20211).

\section{Planning}

In October a revised development plan for Ireland was published - the National Development Plan 2021-2030 (NDP). It outlines a set of national strategic outcomes, including compact growth, enhanced regional accessibility, strengthened rural economies and communities, and sustainable mobility. Proposed projects under the NDP will undergo a climate and environmental assessment before final sign-off. From a local government perspective, the NDP will have a significant impact on the sector. For example:

- there will be a steady rise in the capital allocation to the DHLGH from 2021 to 2025 (from $€ 2,766$ million in 2021 to $€ 4,016$ million in 2025);

- local authorities will move from a shallow to a deep retrofitting programme, with 36,500 council houses expected to be retrofitted by 2030 ;

- there is a commitment to increase staffing levels in housing and planning services to help meet housing delivery targets, and tackle the problem areas of vacancy and dereliction;

- the Urban Regeneration and Development Fund will be extended until 2030;

- nearly €6 billion in investment will be undertaken by Irish Water from 2021 to 2025 .

In total, the NDP promises to allocate $€ 17.6$ billion to the DHLGH from 2021 to 2025 . Housing is a top policy priority, and as local government will be building on scale in the coming years, the bulk of this funding ( $€ 12$ billion) will go towards the delivery of social and affordable housing (Department of Public Expenditure and Reform, 2021).

Housing for All will introduce changes to Ireland's planning system. Under the policy, a new planning advisory forum was established to help 'improve the functioning of the planning system'. The forum held 
its first meeting in December, chaired by the Minister of State for Planning and Local Government, Peter Burke, TD. Its membership is comprised of cross-sector representatives. The forum will advise the minister on planning matters and will also input into a review and consolidation of planning legislation being led by the Office of the Attorney General.

To further drive digitalisation in service delivery, Housing for All commits to the roll-out of an e-planning system in all local authorities by the end of 2022. It will enable members of the public to submit applications, appeal decisions and pay fees all online. Furthermore, responsibility for planning decisions on large-scale residential developments has been returned to local authorities; however, decisions have to be made within a strict timeline (Department of Housing, Local Government and Heritage, 2021f). Indeed, calls were made to ensure that the authorities have the resources necessary to meet the time frame on decisions, if the supply of housing is to increase to the level envisaged by policymakers ('Resources key to success of planning bill', 2021).

\section{Finance}

For 2021 the budgeted current expenditure for local authorities was $€ 5.8$ billion, and for capital expenditure the figure was $€ 4.44$ billion $€ 10.24$ billion in total. This budget compared to $€ 9.35$ billion for 2020 , so a 9.5 per cent increase for 2021 (Department of Housing, Local Government and Heritage, 2021g). It is well documented that the pandemic has severely hit local authority finances. A commercial rates waiver was introduced for most businesses in 2020 as central government made up the shortfall. A modified waiver scheme operated in 2021. From March 2020 to December 2021 the DHLGH distributed nearly $€ 1.5$ billion to local authorities to compensate for the commercial rates waiver (Department of Housing, Local Government and Heritage, 2021e).

In June the Minister for Finance, Paschal Donohoe, TD, introduced long-awaited changes to the Local Property Tax (LPT). Houses built after 2013 were brought under the LPT and the rate of the LPT was reduced and the bands widened. The new valuation for properties will last for a four-year period, and will thereafter be reviewed every four years. New properties will be included in the LPT each November, and local authorities will keep 100 per cent of the LTP collected in their area. The changes are expected to increase 
the tax yield to about $€ 560$ million per year (Department of Finance, 2021). The revised LPT scheme reflected a commitment in the programme for government.

In line with another government promise, in relation to the Moorhead report on the remuneration of elected members, the annual pay of councillors increased from $€ 18,706$ to $€ 25,788$ per year, effective from 1 July. The change was in recognition of the extra responsibilities of councillors since the 2014 reforms and was also intended to modernise the remuneration regime. It is expected to cost the Exchequer up to an extra $€ 9$ million per annum for Ireland's 949 councillors (Department of Housing, Local Government and Heritage, 2021d; S.I. No. 312 of 2021 - Local Government (Remuneration of Local Authority Members) Regulations, 2021).

\section{Local authority performance}

The National Oversight and Audit Commission (NOAC) released its 2020 performance report on the sector in September (National Oversight and Audit Commission, 2021). It provides an objective assessment of how Ireland's local authorities performed in eleven key areas by using forty-two indicators. Understandably, the impact of the pandemic made a comparison with previous years problematic as local authority work programmes were severely disrupted in 2020. Some of the key findings were:

- an increase in the average reletting time for council housing;

- a significant decrease in the average number of library visits per head of population;

- a decrease in the number of adults in emergency accommodation;

- a significant increase in the total number of followers on social media accounts;

- a considerable rise in the percentage of motor tax transactions completed online;

- a decline in the number of jobs created in 2020 by the local enterprise offices.

NOAC acknowledged that local authorities responded effectively to an unprecedented public crisis and maintained service delivery in a challenging financial and working environment. Some $€ 633.2$ million in Business Restart Grants was administered by local authorities, and they received over 57,000 phone calls from people in need through the 
Community Call helplines. Through their engagements with local authorities, NOAC noted common concerns among senior staff:

- uncertain financial situation;

- delivering services amid the ongoing pandemic;

- reduced staffing levels, difficulties recruiting and retaining staff;

- next steps after the rates waiver schemes is eventually discontinued;

- reduced service charge returns;

- increased rent arrears (National Oversight and Audit Commission, 2021).

\section{Directly elected mayor}

There was progress in 2021 on the introduction of Ireland's first directly elected mayor (DEM); however, there was still no election. In January the government approved the drafting of legislation for an elected mayor with executive functions in Limerick City and County. The functions include housing and building, road transport and safety, strategic development and environmental services. The DEM will serve for five years, receive an annual salary of $€ 130,000$ and will be supported by a complement of five staff. Furthermore, the mayor will develop a 'Programme for Local Government in Limerick', which will have to be approved by the elected council. The current chief executive position in Limerick will be renamed 'director general' and will keep responsibilities in terms of managing and accounting for the council's finances (Department of Housing, Local Government and Heritage, 2021b).

A draft General Scheme of a Bill for Limerick's DEM was published in April. It stated that the mayor's programme 'shall have regard to national policies as set out by Government and the obligations of the local authority'. Also, a review of the powers assigned to the mayor will be undertaken by the end of the third year of the term (Department of Housing, Local Government and Heritage, 2021c).

In November the Joint Committee on Housing, Local Government and Heritage released its pre-legislative scrutiny report for the proposed DEM. Among its recommendations to improve the Bill were the following:

- the provision of 'significant additional powers' to the office of DEM so that the position would be in line with international practice; 
- the mayor should have funding and revenue-raising power and be able to appoint all of their own staff;

- the mayor should have the power to reassign the responsibilities of the directors of service within the local authority (Department of Housing, Local Government and Heritage, 2021h).

The matter of Limerick's DEM generated much comment and debate in 2021 as legislators got down to the nitty-gritty of determining which powers the office should hold. The government will consider the committee's recommendations and it hopes to pass the legislation in time for an election in summer 2022, three years after the landmark plebiscite result. Whatever the final powers of the DEM, its introduction will represent a historic change in the structures of Irish local government and its progress will be watched closely in the coming years.

\section{Conclusion}

Covid-19 continued to dominate matters in 2021, particularly at the start and end of the year as new variants brought a sharp rise in case numbers. Local authorities were again at the forefront of dealing with the immediate effects of the pandemic on the ground. However, the year also saw councils take steps to address longer-term societal impacts. For example, 'reimagining' public spaces, developing digital services and planning for the provision of remote working hubs. Furthermore, the launch of promising programmes with the Health Service Executive in 2021 signals a growing local authority role in the promotion of public health and well-being.

The impact of the global pandemic is expected to continue throughout 2022, and its full effects are still rather unknown - there is discussion in some policy circles about a 'Covid decade', during which its lingering impact will be felt (The British Academy, 2021). As local authorities and stakeholders prepare a new round of LECPs, careful consideration will be given to addressing local needs arising from Covid's uneven impact. The flexibility envisaged for the new LECP process should enable local government to be more responsive to changing circumstances and needs.

The role of local government in addressing other public crises (notably housing and climate change), and in advancing regional development, was clearly outlined by policymakers in 2021. With considerable Exchequer funding being directed at these areas, the demands and expectations on local authorities to deliver are high. 


\section{References}

Bradley, L. (2021). A terrible beauty is born. Retrieved from https:/www.ipa.ie/_fileUpload/Documents/LAT\%20SUMMER\%202021. pdf [5 January 2022].

The British Academy. (2021). The COVID decade: Understanding the long-term societal impacts of COVID-19. Retrieved from https:/www.thebritish academy.ac.uk/documents/3238/COVID-decade-understanding-longterm-societal-impacts-COVID-19.pdf [7 January 2022].

Clare County Council. (2021). Works underway to establish Ennistymon as 'destination town'. Retrieved from https:/www.clarecoco.ie/yourcouncil/[news]/works-underway-to-establish-ennistymon-as-destinationtown-.html [7 January 2022].

Climate Action and Low Carbon Development (Amendment) Act. (2021). Retrieved from https:/www.irishstatutebook.ie/eli/2021/act/32/enacted/ en/pdf [6 January 2022].

County and City Management Association. (2021). Delivering effective climate action 2030. Retrieved from https://www.lgma.ie/en/publications/localauthority-sector-reports/delivering-effective-climate-action-2030.pdf [6 January 2022].

County and City Management Association and Local Government Management Agency. (2021). Climate action economic opportunities: Local authorities supporting enterprise policy analysis report. Retrieved from https://www.caro.ie/projects-research/collaborations/economic-andenterprise-opportunities-from-climate [10 January 2022].

Dáil Éireann. (2021). Written answers nos. 826-853. Retrieved from https:/www.oireachtas.ie/en/debates/question/2021-03-03/section/724/ [6 January 2022].

Department of the Environment, Climate and Communications. (2021a). Climate action plan 2021. Retrieved from https:/www.gov.ie/en/ publication/6223e-climate-action-plan-2021/ [6 January 2022].

Department of the Environment, Climate and Communications. (2021b). Ireland's ambitious Climate Act signed into law. Retrieved from https:/www.gov.ie/en/press-release/9336b-irelands-ambitious-climate-actsigned-into-law/ [6 January 2022].

Department of Finance. (2021). Minister Donohoe announces changes to Local Property Tax. Retrieved from https://www.gov.ie/en/press-release/a9a5aminister-donohoe-announces-changes-to-local-property-tax/ [11 January 2022].

Department of Housing, Local Government and Heritage. (2021a). A living tradition: A strategy to enhance the understanding, minding and handing on of our built vernacular heritage. Retrieved from https://www.buildings ofireland.ie/app/uploads/2021/12/A-Living-Tradition.pdf [7 January 2022]. 
Department of Housing, Local Government and Heritage. (2021b). Directly elected mayor for Limerick to be given significant powers. Retrieved from https://www.gov.ie/en/press-release/71519-directly-elected-mayor-forlimerick-to-be-given-significant-powers/ [11 January 2022].

Department of Housing, Local Government and Heritage. (2021c). General Scheme of Local Government (Directly Elected Mayor with Executive Functions in Limerick City \& County) Bill 2021. Retrieved from https://www.gov.ie/en/publication/45a69-general-scheme-of-localgovernment-directly-elected-mayor-with-executive-functions-in-limerickcity-county-bill-2021/ [11 January 2022].

Department of Housing, Local Government and Heritage. (2021d). Government agrees a reform in councillor pay and conditions. Retrieved from https://www.gov.ie/en/press-release/4a350-government-agrees-areform-in-councillor-pay-and-conditions/ [8 January 2022].

Department of Housing, Local Government and Heritage. (2021e). Government announces $€ 62.3 m$ targeted commercial rates waiver for quarter one 2022. Retrieved from https://www.gov.ie/en/press-release/f4ee1government-announces-623m-targeted-commercial-rates-waiver-forquarter-one-2022/ [12 January 2022].

Department of Housing, Local Government and Heritage. (2021f). Government launches Housing for All - A New Housing Plan for Ireland. Retrieved from https:/www.gov.ie/en/press-release/ee5a9-governmentlaunches-housing-for-all-a-new-housing-plan-for-ireland/ [7 January 2022].

Department of Housing, Local Government and Heritage. (2021g). Local authority budgets 2021. Retrieved from https://www.gov.ie/en/collection/ 14e24-local-authority-budgets/ [11 January 2022].

Department of Housing, Local Government and Heritage. (2021h). Minister Burke launches report on Limerick mayor. Retrieved from https://www.gov.ie/en/press-release/386c8-minister-burke-launches-reporton-limerick-mayor/ [11 January 2022].

Department of Housing, Local Government and Heritage. (2021i). Minister Burke welcomes full budget expenditure relating to the provision of Traveller-specific accommodation in 2021. Retrieved from https://www.gov.ie/en/press-release/074e3-minister-burke-welcomes-fullbudget-expenditure-relating-to-the-provision-of-traveller-specificaccommodation-in-2021/ [5 January 2022].

Department of Housing, Local Government and Heritage. (2021j). Minister Noonan announces $€ 8 m$ in funding for built heritage projects. Retrieved from https://merrionstreet.ie/en/news-room/news/minister_noonan_ announces_8m_in_funding_for_built_heritage_projects.171913.shortcut.ht $\mathrm{ml}$ [7 January 2025].

Department of Housing, Local Government and Heritage. (2021k). Minister O'Brien announces enhancements to the Defective Concrete Block Scheme. Retrieved from https:/www.gov.ie/en/press-release/e365e-minister-obrienannounces-enhancements-to-the-defective-concrete-block-scheme/ [7 January 2022]. 
Department of Housing, Local Government and Heritage. (20211). Public consultation on the draft River Basin Management Plan for Ireland 20222027. Retrieved from https://www.gov.ie/en/consultation/2bda0-publicconsultation-on-the-draft-river-basin-management-plan-for-ireland-20222027/ [7 January 2022].

Department of Public Expenditure and Reform. (2021). National development plan 2021-2030. Retrieved from https://www.gov.ie/en/publication/774e2national-development-plan-2021-2030/ [8 January 2022].

Department of Rural and Community Development. (2021). Our rural future: Rural development policy 2021-2025. Retrieved from https://www.gov.ie/en/publication/4c236-our-rural-future-vision-andpolicy-context/ [12 January 2022].

Department of Rural and Community Development and the Department of Housing and Local Government and Heritage. (2021). Local economic and community plans guidelines 2021. Retrieved from https://www.gov.ie/en/press-release/59c83-ministers-humphreys-andobrien-launch-local-economic-and-community-plans-guidelines-2021/ [8 January 2022].

Department of the Taoiseach. (2021). COVID-19 resilience and recovery 2021 - The path ahead. Retrieved from https:/www.gov.ie/en/publication/c4876covid-19-resilience-and-recovery-2021-the-path-ahead/?app $=$ true $\quad[7$ January 2022].

Department of Tourism, Culture, Arts, Gaeltacht, Sport and Media. (2021). Re-imagining our outdoor public spaces. Retrieved from https://www.gov.ie/en/press-release/14d5d-re-imagining-our-outdoorpublic-spaces/ [6 January 2022].

Health Service Executive. (2021). Sláintecare healthy communities. Retrieved from https://www.hse.ie/eng/about/who/healthwellbeing/slaintecarehealthy-communities/ [7 January 2022].

Healthy Age Friendly Homes Programme. (2021). Healthy homes initiative. Retrieved from https://agefriendlyhomes.ie/topics/social-healthcare/healthy-homes/ [7 January 2022].

Lonergan, L. (2021). Works commence on world-class visitor experience at Mount Congreve. Retrieved from https://www.waterfordlive.ie/news/ around-waterford/702259/works-commence-on-world-class-visitorexperience-at-mount-congreve.html [7 January 2022].

National Oversight and Audit Commission. (2021). Local authority performance indicator report 2020. Retrieved from https://noac.ie/2020performance-indicator-report/ [9 January 2022].

'Resources key to success of planning bill' - Fieldfisher. (2021). Retrieved from https://www.lawsociety.ie/gazette/top-stories/2021/11november/resources-key-to-success-of-planning-bill [11 January 2022].

S.I. No. 312 of 2021 - Local Government (Remuneration of Local Authority Members) Regulations. (2021). Retrieved from https:/www.irish statutebook.ie/eli/2021/si/312/made/en/pdf [7 January 2022]. 
Wexford County Council. (2021). Chief executive's report - September 2021. Retrieved from https://www.wexfordcoco.ie/sites/default/files/content/ Report-to-Council-September-2021.pdf [6 January 2022].

Wicklow County Council. (2021). Chief executive's monthly report - July 2021. Retrieved from https://www.wicklow.ie/Portals/0/adam/Documents/ 1QheZdvNn0yG-LQj6uUMxw/Link/Chief\%20Executive\%20Report\%20$\% 20 J u l y \% 202021$.pdf [7 January 2022]. 